\title{
19. The Limburg dialects: Grammatical properties
}

1. General characteristics

2. Word formation in Limburg dialects

3. Morphological variation in word forms (inflection)

4. Syntactic characteristics

5. Conclusion

6. Atlases

7. References

\section{General characteristics}

The Limburg dialect area can be divided into two parts of roughly equal size, which belong to two different nations. This situation has resulted in diverging evolutionary complexes: in the recent past, the western half has more easily integrated into the 'Belgian' context than the eastern half has into the 'Netherlandic' context. New tendencies deviating from SD spread over to the Belgian part, but did not reach the eastern dialects; such tendencies were extremely rare in the south of the Netherlands. This may have resulted in a more conservative position in the eastern part (Netherlands Limburg, henceforth NL), and a rather 'lax' attitude towards 'Belgian' language shifts in the west (Belgian Limburg, BL); we will return to this topic in section 5.

The description of grammatical characteristics in sections 2. (on word formation), 3. (inflectional phenomena) and 4. (syntactic characteristics) are not based on the differences between the two geographical parts. We will, of course, be concerned with the geographical differences in the Limburg area as a whole. The possible impact of divergences will be discussed in section 5 .

\section{Word formation in Limburg dialects}

On the whole, Limburg dialects have the same word formation rules (with respect to derivation and composition) that other Dutch dialects, and SD, have. The dialect literature lists a small number of differences, the most important ones of which are the following:

- The use of - $\partial r$ in adjectival forms such as mastre: $\chi$ tər 'Maastricht, adj.'; $\partial r$ is also used in nominal foms, especially in NL, but it is not always possible to determine whether it is the West Germanic suffix that is involved here, or the reduced form of the Latin loan arius, which also occurs in the rest of the Dutch language area (cf. De Schutter 1983).

- Frequentative nouns derived from verb stems take the circumfix $\gamma \gamma_{-}+-s$, which gives rise to derivations like yalaups 'running about' (SD geloop), yadeuns 'ado' (SD gedoe); cf. Weijnen (1966: 333). 
- sa (< OWG iskô) is used in parts of Limburg (both in the north and the south) to form feminine counterparts of professional names, cf. Weijnen (1966: 332); e.g. in meesterse 'mistress'. The suffix is found in Flemish dialects as well, but not in Brabant, the area between these dialect regions.

The suffix -lijk, which is common to all Dutch language variants, has the 'German' form -liç in the southeastern part of NL (cf. Hinskens 1995). It thus belongs to a small class of morphemes with the High German consonant shift (cf. also section 3.3.). Another formal characteristic is the use of $-d s$ as a nominalization suffix; e.g. debda (SD. diepte) 'depth', cf. Hinskens (1992: section 5.3.16.).

There is one type of derivation where Limburg dialects differ more fundamentally from other Dutch dialects, because of their so called tonal accents (cf. Hermans, ch. 18 in this volume). As we will see in section 3.1.1.3., nouns and also verbs can change TA1 (tonal accent 1 ) into TA2 in the plural, if the plural is expressed concatenatively by a final schwa. A nominal example is: $s j i{ }^{1}{ }^{1}$ ' disk, sg.' vs. sji: ${ }^{2} v a$ 'disk, pl.' (superscripts indicate the tonal accents). In this form the stem-final fricative is voiced at the underlying level; postlexically it is devoiced, because obstruents are always devoiced in final position. A verbal example is: sjri: ${ }^{1}$ ' 'write, 1 p. sg.' vs. sjri: ${ }^{2} v$ ' 'write, 1 p. pl.'. In many dialects this alternation is exceptionless if the phonological conditions are met. There are two such conditions: firstly, the stem should end in a voiced consonant (at least at the underlying level); secondly, the stressed syllable of the stem should end in a segment of low sonority (either a sonorant consonant or a high vowel). There is one derivational process where this alternation is blocked, namely when a verb is derived from a noun without an overt derivational affix. Consider, for instance, the nouns: $s r j u:{ }^{1} v$ 'screw, N. sg.' and $l i:{ }^{1} n$ 'line, N. sg.' The plurals of these nouns are: $s r j u{ }^{2} v a$ 'screw, N. pl.' and $l i{ }^{2}$ na 'line, N. pl.' If these nouns are converted into verbs by zero derivation, then the tonal accents of the stem remain the same, yielding $s r j u:{ }^{1} v$ 'screw, V. 1 p. sg.', srju: ${ }^{1} v a$ 'screw, V. 1 p. pl.', and $l i:{ }^{1} n$ 'line up, V. 1 p. sg.', $l i:{ }^{1}$ na 'line up, V. 1 p. pl.' As far as we know, this phenomenon has not received any attention in the literature, but the relevant data can be found in dialect dictionaries such as Kats (1985) and Endepols (1955).

\section{Morphological variation in word forms (inflection)}

We will give an overview of morphological variation in the following word classes: nouns (section 3.1.), attributive words: adjectives and nominal determiners (section 3.2.), personal and possessive pronouns (section 3.3.) and verbs (section 3.4.).

\subsection{Nouns}

Apart from the stem, which functions as the (simple) singular in Limburg dialects, there are generally two forms: the plural and the diminutive (which itself has a plural form as well). This is similar in all other varieties of Dutch. 


\subsubsection{Plural inflection}

Plural inflection in Limburg dialects makes use of three sets of markers. Like in all Dutch dialects, there are various endings (including zero); stem vowels may be palatalized ('secondary umlaut'), like in most eastern dialects south of the IJssel river; and tone accent alternation, the third phenomenon, is specific to the Limburg region.

\subsubsection{Plural endings}

Adequate overviews of the history of plural formation in the Limburg dialects, in comparison to all other Dutch dialects can be found in Goossens (1987) and MAND I, Commentary: 8-12; a schematic overview of Limburg plural formation is found in Hinskens (1992: section 5.3.18., especially Figure 5.1). Basically there are four plural suffix types in the Limburg dialects; the same endings occur in SD, although the lexical incidence of these types is very different. Abstracting away from occasional class transitions, we can summarize these as follows:

1. Schwa, attached to the singular stem. Historically, this suffix is derived from the weak nasal suffix of Old West Germanic (OWG): [n] was added to the whole stem (including the theme vowel, which also occurred in the singular forms). It is still basically restricted to descendants of the OWG weak classes; examples are be:r 'bear', $o: \gamma$ 'eye', $r i b$ 'rib', cf. the MAND I maps 1.6.1.1-2-4, which show an almost homogeneous distribution of schwa plurals throughout the Limburg area. Pluralization of this type may well have attracted nouns that would otherwise have received the same form in singular and plural; this phenomenon was noted for the late nineteenth-century dialect of Roermond, cf. Simons (1889: 45).

2. A zero ending is the result of apocope of old final schwa, which originated from vocalic plurals in the OWG strong declination types. Apocope was probably facilitated by the occurrence of umlaut and the tone alternation in many word stems. The zero ending survived in all present-day Limburg dialects, as illustrated by Goossens' (1987) maps 1 pöt 'pots', 2 dö(:)(r)n 'thorns', 3 stian/stiin 'stones', 4 ber $\chi$ 'mountains' and 5 pri:s 'prizes', although sometimes the most western dialects have introduced forms with $ə$, cf. the MAND I maps 1.6.1.23 da: $k$ 'roofs', 1.6.1.24 $\gamma$ la:s 'glasses'; for both words BL has schwa plurals.

3. - $-\partial r$ was originally part of the plural stem of the ezlaz class (e.g. eier 'eggs' cf. Goossens 1987: 159 and MAND I, map nr. 1.6.1.26). It was reinterpreted as a suffix that could be added to other neutral nouns, e.g. kinder 'children', cf. Goossens 1987: 160 and MAND I, nr. 1.6.1.25; dipar 'things', MAND I nr. 1.6.1.29; da:kər 'roofs' (only in the southern part of both provinces), nr. 1.6.1.23; gla:zar 'glasses' (not in the western half of BL), nr. 1.6.1.24.

4. $-s$ did not belong to the repertoire of plural endings in eastern dialects. It may have been introduced through the mediation of more western dialects (it had its origin in Flemish and other coastal 'ingvaeonic' dialects), or stem directly from SD. It was successfully recently introduced in most Limburg dialects in a number of formal word classes:

- diminutives, which have singular forms ending in schwa, cf. this chapter, 3.1.2.

- disyllabic words ending in $a+$ sonorant $(l / r / m)$, in both autochthonous words and loans. The MAND I maps concerning plural formation show quite different 
geographical distribution patterns for specific nouns: $-s$ is found almost everywhere in Limburg, with the exception of the extreme southeast, in negers 'black persons' (map 1.6.1.30). In tafels 'tables' (1.6.1.31) and especially meubels 'pieces of furniture' (1.6.1.32) $s$ plurals are commonly restricted to the northern and western parts of the Limburg area, and in appels 'apples' (1.6.1.33) and vogels 'birds' (1.6.1.34) they are even further restricted to the western half of BL.

- a small number of 'relational' nouns: zø:ns 'sons' in the whole area (map nr. 1.6.1.39), brø:rs 'brothers' in the eastern half, with the exception (again) of the extreme southeast (1.6.1.35), and knexts 'male servants' sporadically, especially (though not consistently) in the south of the two provinces (1.6.1.38).

- a small number of words ending in schwa or vowel; e.g. hemdas 'shirts' (cf. MAND I, map nr. 1.6.1.6) and $k R o .{ }^{~}{ }^{2}$ 'crows' (cf. Hinskens 1992: section 5.3.18).

\subsubsection{Umlaut in plurals}

Plurals ending in schwa never have umlaut. Words of this type go back to weak nominal classes, which did not have umlaut originally. They have attracted very few originally strong stems; this only occasionally happened in the west of the Limburg area, where secondary umlaut was weaker than elsewhere. The new plural forms thus adapted completely to the new class into which they were incorporated, and this implied the loss of umlaut; cf. taka as opposed to (eastern) tzk 'branches', MAND I nr. 1.6.1.18.

Words with zero ending take umlaut, whenever the string contains a back vowel; there are some exceptions, like $d a: \chi$ 'days', cf. MAND I, nr. 1.6.1.21; Grootaers (19081909: 280) mentions a few others, especially feminine nouns like $\mathrm{ra:s}$ 'goose' and hand 'hand' in the southern town of Tongeren; cf. also Simons (1889: 45), who lists a few 'exceptions' in the northern dialect of Roermond. In such words (with long stems ending in voiced sounds), singular and plural forms still differ because tonal accent shifts apply, cf. section 3.1.1.3.

Words with - $\partial r$ may be subject to umlaut as well, although there appears to be much variation throughout the area, cf. bla:r/bla: r, MAND I nr. 1.6.1.28; lamər/lemər 'lambs', nr. 1.6.1.27; yla:zər (nr. 1.6.1.24) does not even have one single local variant with a palatal vowel. If we compare this state of affairs with the description of the Tongeren dialect by Grootaers (1908-1909: 282-283), we may conclude that umlauted plurals have lost much ground in the past century (the MAND data were collected in the last quarter of the twentieth century). Perhaps this development took place even earlier, since Simons (1889) already at the end of the nineteenth century states that Roermond mostly had non-umlauted $r$-plurals.

Most remarkably, $s$ plurals tend to take umlaut if the stem vowel is back: both brø:rs and $z ø: n s$ are very frequent (though not in the western part of BL), cf. MAND I, 1.6.1.35 and 39. This may be interpreted as a strong indication that the $s$ ending has been a secondary addition to an already existing form with umlaut.

\subsubsection{Tone accent shifts in plurals}

As in other instances of TA1/TA2 shift, many individual dialects have a marked tendency to give up the alternation in specific words, although it still exists in the great majority of those dialects that had the shift historically. The MAND I maps, designed on the basis of fairly recent data, confirm the idea that the alternation is restricted to stems 
ending in underlyingly voiced consonants (Goossens 1987: 147). Given this restriction, there appear to be two types (cf. also Goossens 2009: 53-55). Firstly, there are words with an alternation between TA1 in the singular and TA2 in the plural. These words have a number of characteristics. Their stressed syllable either contains a vowel that has been lengthened by the historical processes of Open Syllable Lengthening, or Analogical Lengthening, or the stressed syllable contains a segment of low sonority (either a high vowel or a sonorant consonant). Furthermore, these words have lost a historical schwa in the singular. Finally, they have a schwa in the plural. Some examples with a stressed syllable ending in a segment of low sonority are $d u:{ }^{1} v$ 'pigeon, sg.', $d u:{ }^{2} v a$ 'pigeon, pl.' (cf. also section 2.). An example of a word whose vowel has undergone (Analogical) Lengthening is $b e .{ }^{1} r$ 'bear, sg.', $b e .{ }^{2} r$ ' 'bear, pl.', cf. map 1.6.2.1 of MAND I.

The second type consists of words with an alternation that has TA2 in the singular and TA1 in the plural. These words essentially have the same properties as the words just mentioned, with one important difference; they have lost a historical schwa in the plural. Some forms that in some dialects have undergone Analogical Lengthening are $w e: \gamma$ 'road', da: $\gamma$ 'day', leading to alternations such as $w e:{ }^{2} \gamma$ 'road, sg.', we: ${ }^{1} \gamma$ 'road, pl.' and $d a{ }^{2} \gamma$ 'day, sg.', $d a{ }^{1} \gamma$ 'day, pl.' Some examples with a stressed syllable ending in a segment of low sonority are kam 'comb' and arm 'arm' cf. especially the MAND I maps 1.6.2.11-20-21-37 for examples of this type. A few words seem to have an alternation between TA2 in the singular and TA1 in the plural, even though they did not suffer schwa loss in the plural, e.g. $\varepsilon i(\partial r)$ 'egg(s)', kind( $\partial r)$ 'child(ren)', cf. maps 1.6.2.25-26 and zo:n/ø:n-zø:ns), 1.6.2.39.

\subsubsection{Diminutive formation}

Limburg dialects are similar to all other dialects of the Netherlands in maintaining descendants of the OWG suffix ikin. In Limburg, as in most dialect areas, there are no other diminutive suffixes. Mostly we find the form ( $ə) k \partial$; there are three specific diverging surface forms, however:

- $\int \partial$ in all phonological contexts in the extreme southeast of NL (only two attestations in the MAND I maps); this suffix appears to be derived from the eastern (High German) form with consonant shift, çən.

- ( $t$ ) $\int$ following dental stops; cf. MAND I maps 2.7.1.6-7 (for pot $_{\text {dim }}$ 'pot' and voet dim 'foot'), Grootaers (1908-09: 287). Even in this context northwestern BL dialects often have (a) $k \partial$.

- ska following velar consonants, cf. MAND I maps 2.7.1.20-21-22 for bry $\gamma$ 'bridge', $b u: k$ 'belly', tan 'pair of tongs', Grootaers (1908-09: 287).

Umlaut has been retained in a large majority of nouns with a back vowel. There are exceptions, though: a list with forms of the southern BL dialect of Tongeren is found in Grootaers (1908-09: 288-289), e.g. (in the spelling used by the author) drà.nkske ' $\mathrm{drink}_{\mathrm{dim}}$ ', kla.ke 'claw $\mathrm{dim}$ ', valeke 'trap $\mathrm{dim}_{\mathrm{dim}}$. Tone shift, on the other hand, appears to be exceptional, at least in the dialects for which we have information. A constant characteristic is that TA2 in the base form shifts to TA1 in the diminutive; cf. Grootaers (190809: 289) and Goossens (2009: 56-57), for the dialects of Tongeren and Genk in BL, respectively; the geographic distribution of TA2 > TA1 in the pairs man-menəkə 'man - 
$\operatorname{man}_{\mathrm{dim}}$ ', $a: p-\varepsilon: p k \partial$ 'monkey - monkey dim $_{\text {' }}$ and $v u: t-v y: t \rho$ 'foot - foot $_{\mathrm{dim}}$ ' is displayed in MAND II maps 2.7.2.1-4-2. The maps illustrate the lack both of any fixed geographical pattern in the distribution, and of one single phonological context that could underlie the divergences. Such contexts may exist in specific dialects, of course: in Montfort (northeast of NL): the shift TA2 > TA1 is restricted to words ending in an underlyingly voiced consonant (cluster), cf. Bakkes (1996: 137).

\subsection{Attributive words}

Limburg dialects have preserved the OWG three-gender system, which implies that there is, in principle, a threefold opposition between attributive words within NPs. Like in all other varieties of Dutch with three genders, words accompanying plural nouns are treated exactly the same as words used with feminine singular nouns. Formally there are therefore no more than three classes: masculine singular / feminine singular + plural / neuter singular. The threefold opposition may be reduced or even suspended in specific types of words, or in some syntactic contexts (cf. in 3.2.1.).

A further peculiarity of all southern dialects, including Limburg ones, is that there are no morphological differences (either on the segmental or on the tonal level) with respect to the determiner type of the NP (cf. the opposition in contexts with singular neuter nouns between SD een klein kind - het kleine kind 'a small child - the small child').

\subsubsection{Inflectional endings}

Similar to most other southern varieties of Dutch, Limburg dialects, except those in the extreme southeast, have been subject to accusativation, which caused a clear opposition between attributive words, which take $\partial n$ in combination with masculine words, and $\partial$ in combination with feminine words, respectively. Finally, combinations with neutral nouns require a zero ending, independently of the determiner, e.g. a yo:d kind - dat yo:d kind for Montfort (Bakkes 1996: 145).

This generally valid picture needs some specifications:

1. First of all, there are two determiners that have peculiar forms, not recurring in any other attributive words. The whole area has a threefold opposition between de: (m.sg) - di: (pl. and f.sg.) - dat (n.sg.) 'that/those' (cf. Peters 1933: 217). The extreme southeastern part of the region has maintained the old nominative masculine form of the definite article, which creates a threefold opposition: $d \partial r-d \partial-\partial t$; cf. Peters (1937). All other local dialects have $d a n-d o-\partial t$.

2. Both masc. sing. and plural/fem.sing. forms are subject to specific rules:

- $-\partial n$ in attributive words combined with masculine singular words is often reduced to schwa, after apocope of $n$. This may occur in all phonological environments in most eastern dialects: NL and the extreme southeast of BL (although it does not appear to happen consistently in most of the local dialects, cf. the MAND I maps 3.6.1.16-17-19, with adjectives followed by hu:d 'hat' $-o: \chi s t$ 'harvest' - da: $\gamma$ 'day', respectively). Furthermore, it occurs in the whole of the Limburg area in all positions, except before words beginning with $h$ - $d$ or a vowel; cf. the MAND I 
maps 3.6.1.20-21-22 (with bery 'mountain', zak 'bag', pot 'pot', respectively). Before words beginning with $t$ the geographical area with retention of $n$ is even more restricted, to dialects in the east of BL, cf. MAND I, map 3.6.1.18; see also Taeldeman (1980: 225-228), who does not mention the last restriction, however.

- -2 with feminine and plural nouns is lost if the attributive word has a long stem ending in a voiced sound; cf. the MAND I maps 3.6.1.27-30-31-49 (rond 'round', klein 'small', la 'long', ni:w 'new', bru:n 'brown', respectively), cf. Hinskens and Muysken (1986), and, specifically for the northern dialect of Roermond, Kats (1939).

Limburg dialects share the second and third peculiarities just mentioned with the great majority of Brabant dialects, although the conditions may differ slightly among local dialects.

The same distribution of inflectional forms is also noted in the indefinite article (a) $n \partial(n)-\partial n-a$ (cf. Peters 1937, MAND I, maps 3.6.1.13-14-15, with the masculine noun rin 'ring', the feminine pi:p 'pipe' and the neuter rla:s 'glass', respectively) and other determiners: the possessive and the deictic words, cf. De Schutter (1966): maps I, III, both on possessives in NPs with masculine head; MAND I 2.6.1.12 (1st p. neuter / feminine + plural).

A feature that is, in principle, shared by the whole of Limburg (and all other southern dialects) is the use of possessive forms with zero ending in combination with relational nouns such as words for 'father, brother, cousin, friend, mate, servant', e.g. mən/zən $v a: d \partial r$ 'my/his father'. On the whole, the tendency appears to affect fewer relational nouns in the south of Limburg than in the northern half, cf. De Schutter (1996: 77-82, especially map II, p. 80, for the combinations 'his father' and 'his brother') and MAND II (maps 2.6.1.3 for the combinations 'our servant' and 'our father', and 2.6.1.16 for 'our father', in opposition with 'our mother'. Bakkes (1996: 167-171) gives a detailed account of the usage in the rural community of Montfort (northern part of NL), and adds that the possessives mi:n/zi:n shift their TA2 stem accent to TA1 in constructions with relational nouns. This might imply that in this environment the original form has lost a schwa ending, because, as we saw in section 3.1.1.3., such cases typically display tone alternations.

\subsubsection{Stem variation in adjective inflection}

Historically, palatalization of vowels does not occur, and, consequently, plays no role in the inflection of attributive words.

Tone shifts again appear in this grammatical class. They occur in two cases; both of them are restricted to stems ending in a voiced sound, cf. Goossens (2009: 57-58), among others, for the BL dialect of Genk.

- If such a stem (with TA2 e.g. in predicative usage) combines with a feminine word (or a plural one, for that matter, since both require a zero ending in adjectives of this type), the tone shifts to TA1, cf. Taeldeman (1980: 235-236).

- If such a stem combines with a masculine singular word, it takes the ending $ə ;$ concomitantly TA2 changes to TA1; cf. Hermans (2006: 66-68). 
As a result, inflectional forms combining with masculine and feminine words should get the same tonal accent, although they are formally distinct. This is also clearly demonstrated by the MAND I maps 3.6.2.1-2-4 (with the nouns da: $\chi$ 'day' (masc.) + lat 'slat' (fem.), ber $\chi$ 'mountain' (masc.) + kast 'cupboard' (fem.), zak 'bag' (masc.) + myts 'cap' (fem.), respectively); in each member of these pairs, the adjective has TA1 accent.

\subsection{Personal and possessive pronouns}

Among the most intriguing grammatical features of southern dialects of Dutch are their pronominal systems. The Limburg dialect area is not an exception to this, although the pronominal system is fundamentally different from their Flemish and Brabant counterparts. Limburg stands out with an impressive array of specific tendencies.

Probably the most eye-catching fact is the persistence of the original $2 \mathrm{nd} \mathrm{p}$. sing. personal and possessive pronominal forms $d u-d i \chi-d i: n$; only the northwestern quarter of BL no longer has the original singular pronouns, cf. Goossens (1994: 42). This means that there is a fundamental (purely lexical) opposition between the singular form $(d y / d i c ̧)$ and the plural one $(d \check{z} e:(r))$ - the latter may also function as the honorific. It should be noted that a number of urban dialects have joined the other southern dialects (Flemish and Brabant) by giving up the 2nd p. singular and replacing it by the plural word form; among these is Tongeren (cf. Grootaers 1908-1909: 301-302), where the pronoun $d u$ survives only in a small number of set expressions, e.g. $d u\left(\right.$ nə) $\int \varepsilon l a m$ 'you scoundrel'.

But there is much more. Unlike both Flemish and Brabant dialects (and, partially, the Dutch standard language), no complex pronouns of any kind were formed (or introduced from other dialects, for that matter) in the overwhelming majority of dialects. This means that there are no plural forms of personal pronouns containing the element lie(den) 'people'; cf. e.g. SD jul-lie 'you', 2nd p. plural, cf. MAND II, synthetic map 3.6.1.10. Only the southwestern part of BL (the Sint-Truiden area) has forms composed of the pronoun + li:s, e.g. $d \check{z} i$-li:s 'you people'. Nor are there any reduplicated subject forms consisting of a combination of weak and strong forms (as is illustrated in e.g. Flemish $i$-( $j) i j$ ('he') or Flemish-Brabant $a$-gij 'you'); only the northwestern quarter of $\mathrm{BL}$ is comparable to the central Brabant dialects in this respect; cf. Goossens (1994: 57). Last but not least, Limburg dialects do not allow pronominal subjects to be doubled ( $i k$ kom ( ək)ik nog terug 'I come I still back = I'll be back again'). Only in the northwestern quarter of BL do we find a few cases in the SAND I synthetic map 3.1.3.10; these findings are confirmed in the (older) RND data for nr. 17 (ik heb (ik) het niet gedaan), which have doubling of the pronoun $i \chi$ in three local dialects in the extreme west of $\mathrm{B}$.

Consistent with almost all other dialect groups, there is generally an opposition between 'strong' and 'weak' forms with full vowel and schwa, respectively, both in subject and object personal pronouns and in possessives, although there are individual exceptions (e.g. the 1st p. plural possessive ons 'our' does not have a reduced form).

The use of original object pronouns with subject function, a feature often attested in the dialects of Dutch, can also be found. In Limburg, especially in the central north, west of the river Meuse, it is found in the 2nd p. singular dix; cf. De Schutter (1989: 80, map 7), Goossens (1994: 45), De Vogelaer (2008: 171), and MAND II, map nr. 3.6.1.3. A similar phenomenon, found in many Dutch dialects, is the transition of object pro- 
nouns to possessives; this is also found in Limburg, with the rise of hun ('their', originally 'them') as a possessive pronoun. It should be noted that this shift (which, by the way, occurred in many other Dutch varieties as well) is common in the centre and the south of the Limburg area, but did not extend to the north, where we find hø:r; cf. De Schutter (1989: 111-112) and MAND II, map 2.6.1.8.

The pronominal form dix, mentioned above, is one of a set of forms that formally differ from the western and central ones, and are, phonologically, closely related to more eastern ones (of the German type). These include both subject and object pronouns ending in $|\chi|(i \chi-m i \chi-d i \chi-u \chi$ 'I-me-you (2nd p. sing. obj.) - you (2nd p. pl. obj.)' and subject pronouns in /r/ (w/vir-d(j)ir 'we - you (2nd p. pl. subj.), $\varepsilon r$ 'he').

As observed above, most of these pronominal forms have alternatives with schwa instead of a full vowel. This applies both to subject and object forms of personal pronouns and to possessives. There are a number of cases where reduced subject pronouns (which are in fact clitics) differ markedly in proclitic and enclitic position. As a matter of fact, some pronouns undergo reduction more easily, or even exclusively if they are enclitic; an example of this is the 2nd p. sing., for which only full forms are found in proclisis in large parts of Limburg (especially the east); cf. De Schutter (1989: 80, map 7) and De Vogelaer (2008: 172, map 9), whereas schwa does occur in enclisis; cf. De Schutter (1989: 19, map 1) and De Vogelaer (2008: 173, map 10).

\subsection{Verbs}

Limburg dialects are rather traditional in the structure of verb paradigms. On the whole they resemble the OWG origin more closely than any other Dutch dialect group. There are a small number of innovations, however, which deserve our attention.

\subsubsection{Non-finite verb forms include:}

- The bare infinitive, which is used both in nominal function and as a complement to a large number of auxiliary verbs (especially those expressing modality).

- The nominal gerund, which is used with the particle te 'to', originally a preposition governing the dative case formed by adding schwa to the infinitive; deletion of this schwa was accompanied by tone accent shift (Goossens 1964). The gerund only survives for some members of the small class of monosyllabic verbs, e.g. for $d y: n$ 'do', and differs from the regular infinitive in tone (TA1 instead of the 'regular' TA2), e.g.
(1) (hij zal het) $d y:{ }^{1} n \quad \leftrightarrow \quad$ (om/voor het) to $d y:{ }^{2} n$ (he will it) do (in order it) to do '(he will) do (it)' '(in order) to do (it)'.

Goossens does not add any information concerning the geographical distribution of the form; he mentions it only for the dialect of Genk (BL).

- The participial (predicative) gerund, mentioned by Grootaers (1908-09: 310-311), among others. It is formed by adding the suffix $\partial(n)$ te:r $r$ to the verb stem, and is

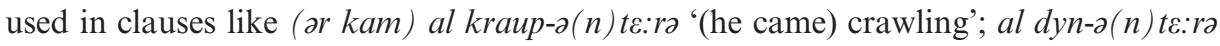


'while doing so'. Notten (1973) gives a map of the geographical distribution: the overwhelming part of $\mathrm{BL}$, and the part of NL adjoining it to the east, have the participial gerund; only the north of NL either did not develop the form or lost it in the course of time.

- The present participle, with the same form as in all other Dutch varieties (stem + and). Grootaers (1908-09: 311) states that the exclusively attributive use of present participles is restricted to a number of set phrases in the dialect of Tongeren, and gives a few examples of NPs with present participles, e.g. de ré $i^{2} z e(n) d e j u: d$ 'the wandering Jew'. In the northern part of Limburg, the 'normal' present participle appears to have the same functions as its SD counterpart.

- The past participle; regular verbs are formed by adding the suffix - $d$ to the stem (cf. Roos 2009); unlike all other Dutch varieties, Limburg does not have a $d / t$ opposition in the suffix (e.g. do rama:gdo afspra:kə 'the appointments that were made' $\leftrightarrow$ SD rəma:ktz).

Like in most Dutch dialects past participles of non-prefixed verb stems take the prefix $\gamma$. The prefix does not appear with some past participles, such as kome 'come ${ }_{\mathrm{PP}}$ ' and blèvə⿸尸 ${ }_{\mathrm{PP}}$ 'remained', in a large number of dialects throughout southern Limburg; cf. Van de Wijngaard (1999) and the MAND II map 5.6.1.7 for rako.ma(n) 'come'.

3.4.2. Finite verb forms are defined on the basis of the following oppositions:

- Moods (3): indicative - conjunctive (restricted to the preterit) - imperative.

- Tenses (2): present - preterit.

- Persons (6): 1st - 2nd - 3rd singular and plural.

3.4.2.1. The imperative has generally only one form, which is used both for singular and plural 2nd $\mathrm{p}$. It ends in a dental stop $(d / t)$, that is deleted in most phonological contexts by the application of the strong $t$ apocope tendency (cf. chapter 8, section 3). A systematic opposition between sing. and pl. / honorific does appear in the southeast of NL.

3.4.2.2. The conjunctive (preterit) forms differ from the indicative counterparts only in non-regular ('strong' and 'irregular') verbs, and only if the preterit stem is susceptible to umlaut. In such verbs the conjunctive has a palatal vowel and the personal endings are the same (e.g. $\partial \chi b o: t-v ə$ bo:tə 'I - we offered (indic.)' $\leftrightarrow \partial \chi b ø: t-v ə$ bø:tə (id., conj.)

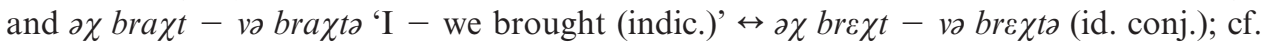
Grootaers (1908-09: 325-332) for the dialect of Tongeren.

3.4.2.3. Preterit formation follows the general lines of modern Germanic languages, with a marked opposition between verbs with formally different present and preterit stems ('strong' and 'irregular' verbs, e.g. ri:d - re:d 'ride - rode', and heb - had 'have had') on the one hand, and those with a preterit suffix added to the stem ('weak verbs'), on the other. The suffix in the latter category is uniformly $d o$ in the greater part of Limburg. We thus find both $d r \varepsilon j$ də 'turned' and ma:gdə 'made', as opposed to SD draaide - maakte, with the opposition telde we also find in all other dialects. The dialects in the extreme southeast of NLL have a deviant suffix form $t$ ( $i \chi$ ma:kət 'I made'; cf. Goossens and Verheyden (1970: 143)). 
3.4.3. Finite verb endings in the Dutch dialects, including Limburg ones, have recently been described in De Schutter (2008, 2010, to appear), De Vogelaer (2008); for some persons and verbs see also MAND II: 50-70. Here we will give only the most salient facts, without referring to the relevant sources:

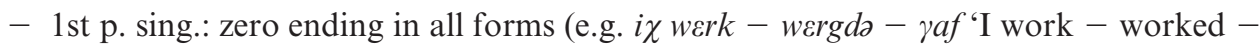
gave'), except the present of the modern a-thematic verbs, i.e. verbs with a stem

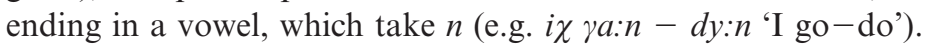

- 2nd p. sing. (only in those dialects that have retained the specific 2 nd p. sing. pronoun): $s$ or $s t$ (the latter form predominantly in the northwest (Roermond) and the

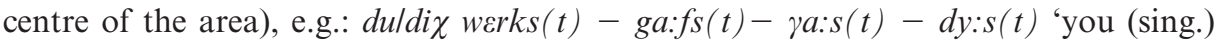
work - gave - go - do'. The regular preterit usually has the form wergdes $(t)$, although a considerable number of dialects have wergzdo, with the personal ending inserted between the stem and the preterit suffix, cf. Goossens and Verheyden (1970: 143).

- 3rd p. sing. and 2nd p. pl. (or 2nd p. sing. + pl. in those dialects that have given up the specific $2 \mathrm{nd}$ p. sing. pronoun) have the same dental stop ending $t$ in all verbal forms except the regular ('weak') preterit forms, where zero ending appears, and 3rd p. sing. 'strong' preterits, equally with zero ending. The dental ending may be lost by syncope, especially before a consonant; this is especially frequent in the southwest of the area but occurs in the northeast as well; cf. also De Wulf and Taeldeman (2006: 251, maps 5-6).

- 1st and 3rd p. pl. Although these forms were not identical in OWG, they have merged absolutely. For most verb forms, this results in final schwa (to be extended to $2 n$ if the next word begins with a vowel). Monosyllabic stems ending in a vowel, however, have either $n$ or $n t$ (e.g. v/wi-zi ya:n/ya:nt 'we/they go'); the latter ending, which was originally restricted to the $3 \mathrm{rd} \mathrm{p}$. pl., is found exclusively in the extreme southeast of the Limburg area.

3.4.4. Apart from the conjunctive forms (cf 3.4.2.2. of this section), umlauted vowels in the verbal paradigms are expected in the $2 \mathrm{nd} \mathrm{p}$. sing. and $3 \mathrm{rd} \mathrm{p}$. sing. present tense forms of 'strong verbs', e.g. dy/diç bäks(t)'you bake' $\leftrightarrow i c ̧ b a k$ 'I bake'. The synthetic map in MAND II, nr. 4.6.1.9 shows that this type of umlaut is far from general in the Limburg area: it is most frequently found in the central and southern part of NL and the adjoining Meuse region in BL, and decreases rapidly as we proceed either to the west or the north.

\subsubsection{Tone alternations within the verbal paradigm}

Verb stems may have TA1 or TA2; cf. Hermans (2006: 60-62); in the former case, all forms will have the same tone throughout the paradigm, e.g. $d r \varepsilon i^{1} \chi-d r \varepsilon i^{1} \gamma d \partial$ ' $[\mathrm{I}]$ threaten - threatened'. Historically, these forms have undergone loss of schwa. In section 3.1.1.3. we saw that schwa drop typically induces TA1. For TA2-stems, there are two possibilities: either the whole paradigm has TA2 (e.g. $h a:{ }^{2} l a-h a:{ }^{2} l d a$ 'get-got', or TA2 shifts to TA1 (e.g. $l \varepsilon:{ }^{2} v \varepsilon-l \varepsilon:{ }^{1} v d$ ). The latter type shows the combined effects of Open Syllable Lengthening and the loss of schwa. In principle a lengthened vowel receives TA2, and this explains why $l \varepsilon:{ }^{2} v \varepsilon$ has TA2. However, in the past tense a schwa has been lost historically, and this explains why the past tense has TA1. Verbs with the 
third pattern all have stems ending in a voiced consonant (Hermans 2006: 62). In this respect these verbs behave similarly to nouns. Recall from section 3.1.1.3. that nouns with a tonal alternation tend to end in an underlyingly voiced consonant.

\section{Syntactic characteristics}

Unlike morphological features, syntactic features cannot be neatly divided into a strictly structured grammatical framework. This makes it extremely hard to draw sharp lines between specific characteristics. In the following state-of-the-art overview we will present some of the most salient features, following the theory-independent classification of syntactic features in De Schutter (1990 and 2002-2003). We also tried to include both features that are common to (almost) all Limburg dialects, but diverge from (many) other groups of dialects, and characteristics that are distinct for specific Limburg dialects. In the latter case we are mostly concerned with east-west oppositions, which sometimes coincide with the state border; north-south oppositions do exist, but are rare.

\subsection{Syntactic markers}

\subsubsection{The factitive subordinating finite conjunction}

Dutch differs from all other modern Germanic languages in that it has a strict requirement on the conjunction dat 'that' in object clauses stating facts. This is also the case in the larger part of the Limburg dialect area; only the southeastern part of NL also has sub-clauses without any conjunction (and consequently with head clause constituent order), like e.g.

(2) (ik zei) ik had mijn voeten pijn gedaan

(I said) I had my feet hurt done

'(I said) I had hurt my feet'

For this structure cf. (i) De Rooij (1965), who includes two maps (p. 110-111); the first one is based on the translations of the Wenker clauses (1924-34), the second on the more recent RND data, and (ii) SAND I, map 1.3.1.8. East Limburg, especially in the south, is the only part of the southern language area that has retained both possibilities.

Non-embedded object clauses are categorically marked by the use of the conjunctive, cf. Hinskens (1992: section 5.3.11.) for the east Limburg (partly Ripuarian) dialects.

\subsubsection{The factitive subordinating non finite conjunction}

Limburg joined all other southern dialects in gradually replacing the old prepositional conjunction om 'in order (to)' by voor in most types of control sentences; this tendency was much stronger, however, in BL (especially in the south) than in NL; cf. Ryckeboer 
(1983: 84, maps 1-2), AND (maps 28-29-30); cf. Cornips (1994: 71) for the NL area. Another possibility was to substitute $\mathrm{om}$ by van:

(3) het is goed van te weten... it is good of to know 'it is good to know'

The latter substitution is not found at all in NL, whereas it is (with one exception) the only construction mentioned for BL in AND map 35.

\subsubsection{The presentative word (English there)}

The medieval usage of $\partial t$ 'it' was maintained in a small southeast part in NL and the Belgian Voerstreek south of Maastricht; e.g. at wa:ra vi:f pri:zə 'there were five prizes'; cf. De Schutter (1989: 86), Hinskens (1992: section 5.3.20). The rest of Limburg predominantly uses $d a:(r)$ 'there'.

Another feature concerning the presentative word is that Limburg dialects tend to leave it out in certain contexts; at least two such contexts are mentioned:

- after subordinating words, cf. AND map 19 in constructions like (4), where it is at a 'long distance' from the NP subject, and in (5), cf. SAND I map 2.4.3.;

- in sentences starting with a local expression such as (6), cf. De Rooij (1991: 113), Hinskens (1992: section 5.3.20.)

(4) wie denk je dat (or/da:rlat) komt who think you that (there) comes 'who do you think will come?'

(5) ('t is net) of (ar/da:rlat) een hond in deze kast zit it is just) if (there) a dog in this cupboard sits (it is just) as if there were a dog in this cupboard

(6) in $X$ is (ar/da:r/at) een bloemenwinkel in $\mathrm{X}$ is (there) a flower shop 'in $\mathrm{X}$ there is a flower shop'

The construction in (4) without the presentative word is reported in the whole area except the southwest of BL; the type illustrated in (5) appears to be current in the southeast of NL, cf. Hinskens (1992: section 5.3.20.).

\subsubsection{Periphrastic doen (English do)}

Doen is used as a supporting auxiliary in all types of clauses (declarative, interrogative, imperative and negative) in NL (not in BL), cf. the synthetic map 3.3.2.1.5 in SAND II. It is reported especially frequently in the south, but is far from absent in the northern 
half. It does not appear west of the Meuse river (BL). Doen is used to emphasize the habitual status of the action expressed by the verb, cf. Cornips (1994: 61-66).

(7) iç dy:n (een keer in de week) nar min mo:dar ya:n

I do (one time in the week) to my mother go

'I usually go to my mother's once a week'

\subsection{Construction types}

\subsubsection{The IPP construction}

The use of infinitives instead of past participles with an infinitive complement is a very common innovation in most Dutch dialects: * (hij) heeft (het) gewild gP $_{\text {doen I doen }}$ gewild $_{P P}$ '(he) has wanted ${ }_{P P}$ to do (it)' was generally replaced by

(8) (hij) heeft (het) willen $_{\text {inf }}$ doen / doen willen $_{\text {inf }}$

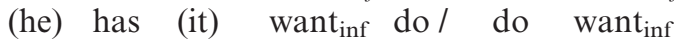
'(he) has wanted to do (it)'.

On the whole, Limburg dialects also follow this general tendency, but there are a few marked exceptions, at least in parts of the Limburg dialect area.

The most remarkable case is what happens to beginnen 'begin' in threefold verbal groups of the type [tense aux. - beginnen - complement verb with te], e.g.

(9) (het) is begonnen $_{P P}$ te / beginnen inf $_{\text {te }}$ vriezen

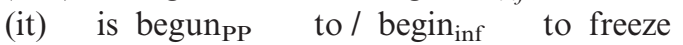

'(it) has started freezing';

Let us look at De Rooij (1981: map p. 25): constructions with the past participle are given in the whole Limburg area, but in BL they are clearly and massively overruled by the construction with infinitive (IPP), which is the dominant one in all other dialects of Belgium as well. NL keeps to the past participle construction; the structure with infinitive is almost completely absent from NL.

A similar, although not identical, picture emerges from De Schutter's (1974) map of the distribution of variants for (hij) is wezen vissen '(he) has been [away] to fish'; in this structure Limburg dialects do not have IPP at all: they use the past participle rowe:s $(t)$.

There is a geographic opposition, however, concerning the order of the verb concatenation: the PP rawe:s $(t)$ usually occupies the final position, but the northeast part (in $\mathrm{NL}$ ) has the to-infinitive following the PP; cf. also Bakkes (1996: 184) for this construction for the dialect of Montfort:

(10) hij is geweest vissen/vissen geweest he has been fish inf $_{\text {fish }}$ inf been 'he has been fishing' 


\subsubsection{Lowering of the non-finite I-marker te}

Meeusen (1943, cf. map II) discusses the remarkable construction illustrated in (11)

(11) (om/voor dat) [kunnen [te doen]

(in order that) be able [to do]

'(in order) to be able to do (that)'

In (11), the I-marker te, which takes the complete verbal group as a complement (cf. SD (om dat) te [kunnen [doen]] '(in order) to be able to do (that))' is lowered to an infinitive that functions as a complement (doen 'do') to the higher verb kunnen 'be able' in the concatenation. The construction seems to be a southern innovation, which spread across large parts of southern Brabant and (even more homogeneously) to the whole of Belgian Limburg. Meeusen did not have any data from adjacent parts of the Netherlands (including NL), but it is unlikely that the construction crossed the River Meuse, i.e. the present state border. As a matter of fact, no dialect description we consulted mentions it.

\subsubsection{Subject and object expressions of the beneficiary/experiencer}

SD mostly uses either prepositional phrases to express the beneficiary of an action or process, or the person experiencing it, or expressions in which the person functioning in this role is expressed by a possessive pronoun; cf. respectively hij heeft een pak voor zijn zoon gekocht 'he bought a suit for his son', and zijn band is lek 'his tyre is punctured'. Many Dutch dialects follow the same line, but Limburg dialects are among the ones that have ways to express these roles by means of NPs, either as subjects, or as (indirect) objects, cf. Van Bree (1981) and Cornips (1994: sections 5.-8.) for very accurate discussions. These expressions include:

1. Beneficiary/experiencer as the subject of a clause with hebben; Van Bree mentions clauses like:

(12) Hij heeft de band lek he has the tyre punctured 'his tyre is punctured'

(13) Hij heeft de vrouw ziek in bed (liggen) he has the woman sick in bed (lie) 'his wife is (lying) sick in her bed'

2. Beneficiary/experiencer as the indirect object of a transitive construction:

(14) Hij heeft me een nieuw pak gekocht he has me a new suit bought 'he bought a new suit for me'

(15) Hij heeft zich een nieuw pak gekocht he has himself a new suit bought 'he bought a new suit (for himself)' 
(16) Hij dronk zich een kop koffie he drank himself a cup (of) coffee 'he drank a cup of coffee'

The difference between (15) and (16) is that in the latter the experiencer is inherently the same as the person referred to by the subject.

Many of the constructions exemplified in (12-16) are common in Standard German. Within Limburg, the geographical divergences between the cases exemplified above are considerable. On the whole, we may say that NL makes use of all NP constructions mentioned, cf. also Bakkes (1996: 182-184) and Cornips (2003: 62-82). Only for the constructions in (13) and (16) there is a further restriction: the northern part of NL generally rejects the construction with NP beneficiary / experiencer in these types; cf. Van Bree's maps 5 and 6. The constructions in (12) and (15) (maps 1 and 4) are generally accepted in NL and in the eastern part of BL. The construction type in (14) appears to be accepted throughout the whole Limburg area; it is also the only type mentioned that is found in the whole southern part of the Dutch language area in Belgium; cf. also Colleman and De Vogelaer (2002-2003). The SAND I maps 4.3.7.3-4-5, based on data collected more recently, present roughly the same picture, but with a marked reduction of the affected area, especially in BL.

The overall conclusion has to be that the construction types present in Limburg belong to the eastern cluster of dialects of Dutch which are closely related to dialects in Germany. But as we cross the river Meuse into BL, western patterns begin to take over. Only for type 2.1 , where the whole southern context converges at least partly with that in the east, does BL fully adopt the general Limburg construction.

The fact that NPs are more prominent in Limburg than in most other dialect areas, which prefer PPs, at least if the beneficiary or experiencer is expressed, seems to have a parallel in the nominal indirect object proper (e.g. ze vertelden het (aan) hun vrienden 'they told it (to) their friends'), which is more often than not used without any preposition in Limburg; all other southern areas have the opposite preference; cf. AND, map 18.

\subsubsection{Inflected COMPs}

SAND I map 1.3.2.3 describes inflection of subordinating words for the whole Limburg dialect area. The only systematic case on which this is based is the fact that the $2 \mathrm{nd}$ p. sing. ending $s(t)$ appears when the subject is enclitic to 'you', e.g. in dasta / wenstz $k o m s(t)$ 'that you / when you come'. An excellent discussion of different views concerning the concatenation of original verb ending and subject clitic can be found in De Vogelaer (2008: 135).

\subsection{Word and constituent order}

\subsubsection{Auxiliaries and their syntactic verbal complements}

The Limburg region differs markedly from both Flanders and central and southern Brabant in the choice between the two possible patterns [aux + PP] or [PP + aux] in subordinate clauses, e.g. 
(17) (dat ze het verhaal) heeft verteld / verteld heeft (that she the story) has told / told has 'that she has told the story'

Whereas the former pattern is almost completely absent from West and East Flanders dialects and is rare in the province of Antwerp and in South Brabant, Limburg dialects display both patterns; cf. Pauwels (1953: synthetic map 16), SAND II (14-15, maps 1.3.1.1-2), and Bakkes (1996: 190-191). These data are fully confirmed by the RND data for nrs. 16 (dat ik niet met ze meegegaan ben / ben meegegaan 'that I have not gone (= did not go) with them') and 134 (dat ik u gezien heb / heb gezien 'that I have seen you').

The same tendency to retain the freedom of choice between the two patterns (present in all variants of Dutch from the late Middle Ages on) also exists for combinations of modal auxiliaries with infinitive complements, like e.g.

(18) (dat jij het ook niet) mag zien / zien mag (that you it also not) may see / see may '(that you) are not allowed to see (it either)'

For the construction in (18) cf. Pauwels (1953: synthetic map 17), SAND II: 15, map 1.3.1.3. It should be noted that here, according to the SAND data, most dialects of BL are like all Flemish and Brabant dialects in rejecting (or at least not preferring) [inf + aux]; but NL and a small number of southeast BL dialects report both patterns. Pauwels' older data show an even distribution in the larger part of BL. Thus, there appears to have been a marked tendency towards favouring [aux + inf] during the last few decades; in this respect $\mathrm{BL}$ follows the rest of the B part of the language area. NL appears to respect the traditional freedom of expression, although Bakkes (1996: 190-191) states that [inf + aux] is practically absent from the spontaneous speech of younger Montfort dialect speakers.

\subsubsection{Interruption of verbal end groups}

One of the peculiarities of all continental West Germanic languages is the fact that auxiliaries and their verbal complements are agglutinated into a firm concatenation of verbal elements at the end of the clause.

Southern dialects of Dutch have a relatively strong tendency to give up this formal unity within the final verb group; the tendency is very strong in the west (Flemish dialects) and grows weaker as we proceed to the east. Still, the RND data (nr. 53: (zijn vader heeft hem zes jaar lang) [naar school] laten gaan / laten [naar school] gaan '(his father has) let him go [to school] (for six years)' show that some $25 \mathrm{BL}$ informants replaced the 'Dutch' constituent order naar school laten gaan, which was presented them, by the pattern with [aux-inf] separated by the primary complement naar school 'to school'; cf. Koelmans (1965: 159), Vanacker (1964: 163-164). In NL not a single informant used the pattern dividing the final verb group into two.

The interruption of verb groups by other constituents than the primary complement (the complement originating within the VP) is extremely rare in BL, if compared to 
southern Brabant and especially Flemish dialects, where interruption even by argument NPs (e.g. dat hij zelfs zou [zijn ouders vermoorden] 'that he would even [murder his parents]' is very common; cf. SAND II, synthetic map 2.3.1.7.

Summing up, it is clear, once again, that tendencies that have a stronghold in the west and centre of the Dutch-speaking part of Belgium are gaining a moderate grip on the BL dialects, but are arrested by the state border.

\section{Conclusion}

In this section we summarize the most interesting findings of our discussion of Limburg dialects. The Limburg dialects appear to be rather traditional in the occurrence and maintenance of grammatical properties inherited from OWG. This applies to both morphological and syntactic characteristics, e.g. the extensive role of umlaut in morphological processes, the retention of the conjunctive, the retention of $2 \mathrm{nd} \mathrm{p}$. sing. pronouns and verb forms, and the (traditional) free choice between patterns in auxiliary constructions.

At the same time, there are a restricted number of innovative tendencies, the most interesting of which is the development of tonal accent oppositions.

It stands to reason that there are also divergences among Limburg dialects. To start with, there are oppositions between the Belgian and the Netherlandic dialects; but both in BL and NL some tendencies and even rules are restricted to specific parts:

- in BL these divergences may be found in the four quarters: the northwest, northeast, southwest and southeast;

- NL has marked differences between the northern and southern half. Within the former area, some minor tendencies divide the northwest and northeast, but we will not go into detail. A far more prominent dividing line separates the extreme southeast from the rest of the south.

It should be noted that the geographical parts just mentioned cannot be delimitated clearly; i.e. the local dialects for which specific tendencies are found may vary considerably. On the whole, however, the subdivision into seven geographical parts seems adequate to capture the dialect diversity. To wind up our discussion, we give a table representing the distribution of 20 of the most salient oppositions discussed in this chapter. All oppositions are binary; we add the 'default specification': + if the feature as it is formulated is relatively common in the Limburg dialect landscape, - if it is not.

1 Occurrence of $s$-plurals [+]

2 Tonal accent shift in plurals $[+]$

3 Diminutive suffix with palatalized onset $[+]$

4 Def. art. m. sing. $=\operatorname{dor}[-]$

5 Complex plural pronouns [-]

6 Reduplicated subject pronouns [-]

7 Possessive pronoun 3rd p. plural $=$ hyn $[+]$

8 Existence of participial gerund $[+]$

9 Weak preterit suffix at $[-]$

$101 \mathrm{st} / 3 \mathrm{rd}$ p. plural ending $-n t$ in verbs with vocalic stems [-]

11 Non-embedded finite object clauses (without subordinating conjunction) [-] 
12 Non-finite conjunction van instead of om [-]

13 doen 'do' as a habitual auxiliary $[-]$

14 Presentative marker $=\partial t[-]$

15 Lowering of I-marker te [-]

16 is beginnen + (te) infinitive $[-]$

17 gewees is + infinitive [-]

18 Interruption of verbal groups possible [-]

19 Maximal occurrence of beneficiary NP $[+]$

20 [inf.-aux] order possible [+]

In Table 19.1 we list all deviations from the default specifications. As for NL, the term southwest (SW) here actually refers to the south in general, except for the southeasternmost area (SE). Also with respect to NL, there appears to be no good reason to distinguish between NW and NE.

If these grammatical phenomena are representative for the Limburg dialect area, and if the default specifications are correct, the list would identify the 'prototypical Limburg dialect'. It is clear that the NL south (minus the extreme southeast) is the region that comes closest to the 'prototypical' Limburg dialect region, only slightly more so than the NL north. The BL eastern quarters follow at short distance. The farthest away from the prototype (with 7 out of 20 characteristics) are the two BL western quarters on the one side and the NL southeast on the other; the former ones have incorporated a large number of 'Brabant' characteristics, whereas the latter betrays its allegiance with eastern Ripuarian dialects.

Although we feel confident that the grammatical phenomena that form the basis of our table are really representative of the Limburg diversity, the geographical picture needs

Tab. 19.1: Deviant specifications for 20 grammatical features in seven regions of the Limburg dialect area

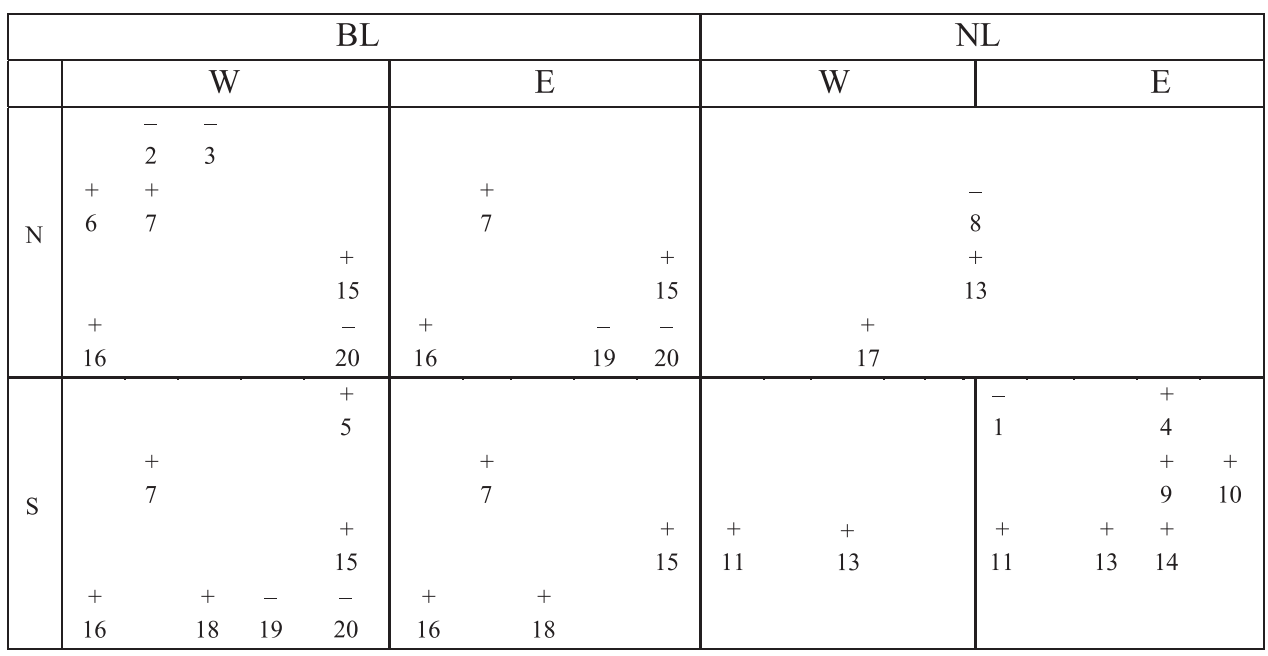


to be elaborated and refined. Further research is called for especially with respect to two intriguing questions:

- the role of the tonal accents in morphology

- the roles of non-Limburg language varieties in the divergence of BL and NL.

\section{Atlases}

RND $\cdot$ AND $\cdot$ MAND $\cdot$ SAND

\section{References}

Bakkes, Pierre

1996 Variatie en verandering in het Montforts: taalstructurele en sociolinguistische aspecten van een veranderend dorpsdialect. Ph.D. thesis, Nijmegen University.

Colleman, Timothy and Gunther De Vogelaer

2002-2003 De benefactiefconstructie in de zuidelijk-Nederlandse dialecten. In: Sjef Barbiers, Magda Devos and Georges De Schutter (eds.), Dialectsyntaxis in bloei. Taal en Tongval. Themanummer 15-16: 184-208.

Cornips, Leonie

1994 Syntactische variatie in het Algemeen Nederlands van Heerlen. Ph.D. thesis, University of Amsterdam. Amsterdam: IFOTT.

De Rooij, Jaap

1965 I knew you knew he knew. Taal en Tongval 17: 105-123. Also in: Jan Stroop (1983), Nederlands Dialectonderzoek - Artikelen uit de periode 1927-1982, 231-246. Amsterdam: Huis aan de Drie Grachten.

De Rooij, Jaap

1981 Het is gisteren beginnen te vriezen. Taal en Tongval 33: 23-30.

De Rooij, Jaap

1991 Regionale variatie in het gebruik van er. III. Taal en Tongval 43: 113-136.

De Schutter, Georges

1966 De verbuiging van het onbepaald lidwoord en van een aantal bijvoeglijke woorden in de Zuidnederlandse dialecten. Taal en Tongval 18: 71-99.

De Schutter, Georges

1974 Wezen vissen; dialektgeografie van een konstruktie. Taal en Tongval 26: 70-85. Also in: Jan Stroop (1983): Nederlands Dialectonderzoek - Artikelen uit de periode 1927-1982, 265- 278. Amsterdam: Huis aan de Drie Grachten.

De Schutter, Georges

1983 Appellatieven in de Nederlandse dialecten. Taal en Tongval 35: 27-32.

De Schutter, Georges

1989 Pronominale clitica in de Nederlandse dialecten. Antwerp Papers in Linguistics 58. Wilrijk: University of Antwerpen.

De Schutter, Georges

1990 De studie van de syntaxis van de Nederlandse en Friese dialecten. Dialectsyntaxis. Taal en Tongval. Themanummer 3: 10-47.

De Schutter, Georges

2002-2003 De Nederlandse en Friese dialectsyntaxis sedert 1990. Dialectsyntaxis in bloei. Taal en Tongval. Themanummer 15-16: 10-43. 
De Schutter, Georges

2008 Werkwoordvormen in de zuidelijke Nederlandse dialecten - Stamkeuze en werkwoorduitgangen - Analyse en beschrijving op basis van het RND-materiaal, deel I. 1 ev. Taal en Tongval 60: 121-171.

De Schutter, Georges

2010 Werkwoordvormen in de zuidelijke Nederlandse dialecten - Stamkeuze, werkwoorduitgangen en fonologische aanpassingen van de stam - Analyse en beschrijving op basis van het RND-materiaal, deel II. 1/3 mv. Taal en Tongval 62: 119-162.

De Schutter, Georges

to appear Werkwoordvormen in de zuidelijke Nederlandse dialecten - Stamkeuze, werkwoorduitgangen en fonologische aanpassingen van de stam - Analyse en beschrijving op basis van het RND-materiaal, deel III. 2 ev/mv - 3 ev. Taal en Tongval 63.

De Vogelaer, Gunther

2008 De Nederlandse en Friese subjectsmarkeerders: geografie, typologie en diachronie. Ghent: KANTL.

De Wulf, Chris and Johan Taeldeman

2006 T-deletie in de Nederlandse dialecten: een globaal overzicht. In: Leonie Cornips, Marc van Oostendorp and Georges de Schutter (eds.), Het morfologisch landschap van het $\mathrm{Ne}$ derlands. Taal en Tongval. Themanummer 19: 244-272.

Endepols, Hubert J. E.

1955 Woordenboek of diksjenaer van 't Mestreechs. Maastricht: Boosten en Stols.

Goossens, Jan

1964 Een tweede Limburgs gerundium. Taal en Tongval 16: 103-106.

Goossens, Jan

1987 Schets van de meervoudsvorming der substantieven in de Nederlandse dialecten. Taal en Tongval 9: $141-173$.

Goossens, Jan

1994 Sprachatlas des nördlichen Rheinlands und des südöstlichen Niederlands, "Fränkischer Sprachatlas". Zweite Lieferung. Marburg: N. G. Elwert.

Goossens, Jan

2009 De Genker toonaccenten en hun dialectgeografische inbedding. Werken van de Koninklijke Commissie voor Toponymie en Dialectologie 27. Tongeren: Georges Michiels N.V.

Goossens, Jan and Jacobus Verheyden

1970 De preteritumvormen van de zwakke werkwoorden in het zuiden van het Nederlandse taalgebied. In: Pieter Meertens, Caron van Coetsem, Mitzka Van Haeringen and Pèe Stutterheim (eds.), Zijn akker is de taal. Opstellen aangeboden aan prof. dr. K. Heeroma, 133-147. Den Haag: Bert Bakker/Daamen.

Grootaers, Ludovic

1908-1909 Het dialect van Tongeren. Eene phonetisch-historische studie. Leuvensche Bijdragen 8: $101-257,267-353$.

Hermans, Ben

2006 De tonologie van onbeklemtoonde lettergrepen in een Limburgs dialect. In: Leonie Cornips, Marc van Oostendorp and Georges de Schutter (eds.), Het morfologisch landschap van het Nederlands. Taal en Tongval. Themanummer 19: 55-70.

Hinskens, Frans

1992 [1996] Dialect levelling in Limburg. Structural and sociolinguistic aspects. Ph.D. thesis, University of Nijmegen. [Abridged and revised version under the same title. Tübingen: Niemeyer.]

Hinskens, Frans

1995 Dialectnivellering in Limburg; het suffix -lijk in Rimburg, Gramma/TTT 4: 1-23. 
Hinskens, Frans and Pieter Muysken

1986 Formele en functionele benaderingen van dialectale variatie: de flexie van het adjectief in het dialect van Ubach over Worms, In: Cor Hoppenbrouwers, Ineke Schuurman, Ron van Zonneveld and Frans Zwarts (eds), Syntaxis en lexicon; veertien artikelen bij gelegen-

Kats, J. C. P. heid van het emeritaat van Albert Sassen, 13-24. Dordrecht/Providence: Foris.

1939 Het phonologisch en morphonologisch systeem van het Roermondsch dialect. Roermond: Romen.

Kats, J. C. P.

1985 Remunjs woardebook. Roermond: H. van der Marck en Zonen.

Koelmans, Leendert

1965 Iets over de woordorde bij samengestelde predikaten in het Nederlands. De Nieuwe Taalgids 58: $156-165$.

Meeussen, E.

1943 Vier isotagmen. Leuvensche Bijdragen 35: 47-57.

Notten, Jan G. M.

1973 De Chinezen van Nederland. Valkenburg aan de Geul: Het land van Valkenburg.

Pauwels, Anita (ed.)

1953 De plaats van hulpwerkwoord, verleden deelwoord en infinitief in de Nederlandse Bijzin. Leuven: Drukkerij M. and L. Symons.

Peters, P.

1933 De vormen en de verbuiging der pronomina in de Nederlandsche dialecten. Onze Taaltuin 1: $6,249-259$.

Peters, P.

1937 De geslachtsvormen van het adjectief in de Nederlandsche dialecten. Onze Taaltuin 5: $357-379$.

Roos, Nieke

2009 The weak past tense in Dutch and Low German. Ph.D. thesis, Radboud University Nijmegen.

Ryckeboer, Hugo

1983 Voor te + infinitief. Verkenning naar de dynamiek van een dialectisme. Taal en Tongval 35: $83-91$.

Simons, Lion

1889 Het Roermondsch dialect getoetst aan het Oud-Saksisch en Oud-Nederfrankisch. Ghent: Koninklijke Vlaamsche Academie.

Taeldeman, Johan

1980 Inflectional aspects of adjectives in the dialects of Dutch-Speaking Belgium, In: Wim Zonneveld, Frans van Coetsem, Orrinn Robinson (eds.), Studies In Dutch Phonology. Dutch Studies, vol. 4, 221-245. The Hague: Martinus Nijhoff.

Van Bree, Cor

1981 Hebben-constructies en datiefconstructies binnen het Nederlandse taalgebied. Een taalgeografisch onderzoek. Ph.D. thesis, University of Leiden.

Van de Wijngaard, Ton

1999 Blève, kòmme, krèje, vònge, woëde i kaat braat. Jaarboek van de Vereniging voor Limburgse Dialect- en Naamkunde, 79-90.

Vanacker, V. Frits

1964 Is het algemeen Nederlands? Taal en Tongval 16: 159-164.

Weijnen, Antonius A.

1966 Nederlandse Dialectkunde. Tweede druk. Assen: Van Gorcum. 